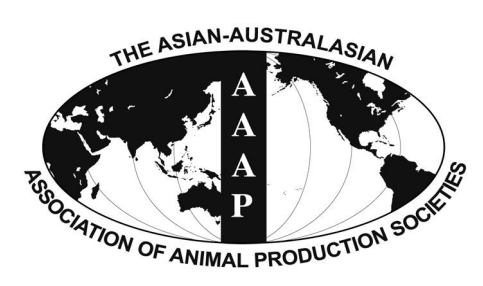

\title{
Effects of Supplements with Different Protein Contents on Nutritional Performance of Grazing Cattle During the Rainy Season
}

\author{
J. F. Figueiras, E. Detmann, M. O. Franco, E. D. Batista ${ }^{1, *}$, W. L. S. Reis, \\ M. F. Paulino, and S. C. Valadares Filho \\ Department of Animal Science, Universidade Federal de Viçosa, Viçosa, MG 36570-900, Brazil
}

\begin{abstract}
The objective of this study was to evaluate the effects of supplements with different crude protein $(\mathrm{CP})$ contents on grazing cattle intake, digestibility, ruminal fermentation pattern, and nitrogen $(\mathrm{N})$ metabolism characteristics during the rainy season. Five ruminal and abomasal cannulated Holstein $\times$ Zebu steers ( $296 \mathrm{~kg}$ body weight, BW) were used in a $5 \times 5$ Latin square design. The animals grazed five signal grass paddocks $(0.34 \mathrm{ha})$. The five treatments evaluated were: Control (no supplement) and $1.0 \mathrm{~g}$ of supplement $/ \mathrm{kg} \mathrm{BW}$ with $0,330,660$, and $1,000 \mathrm{~g}$ of $\mathrm{CP} / \mathrm{kg}$ as-fed. The supplement was composed of starch, soybean meal, urea, and ammonium sulphate. There was a positive linear effect $(\mathrm{p} \leq 0.033)$ of the $\mathrm{CP}$ content in the supplements on the organic matter $(\mathrm{OM}), \mathrm{CP}$, and digested OM intakes. The provision of supplements did not increase ( $\mathrm{p} \geq 0.158)$, on average, total and ruminal digestibilities of OM and CP. However, the increase in CP content in the supplements caused a positive linear effect $(\mathrm{p} \leq 0.018)$ on ruminal digestibilities of $\mathrm{OM}$ and CP. Additionally, a quadratic effect of the CP contents of the supplements were observed $(\mathrm{p}=0.041)$ for the ruminal digestibility of neutral detergent fiber corrected for ash and protein, with the highest estimate obtained with the CP content of $670 \mathrm{~g} / \mathrm{kg}$. The supply of supplements increased $(\mathrm{p}<0.001)$ the ruminal ammonia $\mathrm{N}$ concentration, which also changed linearly and positively $(\mathrm{p}<0.001)$ according to increase in CP content in the supplements. The apparent $\mathrm{N}$ balance and relative $\mathrm{N}$ balance $(\mathrm{g} / \mathrm{g} \mathrm{N}$ intake) were not, on average, changed $(\mathrm{p} \geq 0.164)$ by the supplements supply. However, both showed a tendency of a linear increase ( $\mathrm{p} \leq 0.099)$ with increasing supplement $\mathrm{CP}$ content. The supplements increased $(\mathrm{p}=0.007)$ microbial $\mathrm{N}$ production in the rumen, which also changed linearly and positively $(p=0.016)$ with increasing supplement CP content. In conclusion, protein supplementation in grazing cattle during the rainy season, while stimulating voluntary forage intake, results in higher efficiency of $\mathrm{N}$ utilization when compared to energy supplementation. This is a possible response to increased microbial protein synthesis in the rumen and improved $\mathrm{N}$ status in the animal body. (Key Words: Digestibility, Energy, Metabolism, Nitrogen, Supplementation, Tropical Forages)
\end{abstract}

\section{INTRODUCTION}

The majority of tropical beef cattle production is based on tropical grasses under grazing as the primary nutrient resource. Such characteristics are determined by the relatively low cost of digestible energy from grasses, mainly from fibrous compounds (Paulino et al., 2008). However, tropical grasses are rarely considered to represent

\footnotetext{
* Corresponding Author: E. D. Batista. Tel: + 55-66-99908-1319, Fax:+55-31-3899-2252, E-mail: erickdarlisson@gmail.com

${ }^{1}$ Institute of Agricultural and Environmental Sciences, Animal Science, Universidade Federal de Mato Grosso - Campus Sinop, Sinop, MT 78557-267, Brazil.

Submitted Feb. 16, 2016; Revised Mar. 9, 2016; Accepted Mar. 18, 2016
}

a balanced diet for grazing cattle, as they exhibit one or more nutritional constraints which may limit forage intake, digestibility, or the metabolizability of absorbed substrates. For this reason, and in order to avoid constraints on animal production via an appropriate supplementation program, a demand exists for the identification of the nutritional limitations of tropical pastures. This would result in improvements in animal performance and the overall production efficiency (Detmann et al., 2014a, b).

During the rainy season, tropical grasses present faster growth and greater nutritive value compared to the dry season. Nevertheless, regarding improved animal performance, the utilization of the nutrients from pastures during rainy season is not considered to be optimal. 
According to studies in Australia and Brazil, a potential improvement in weight gain of $200 \mathrm{~g} / \mathrm{animal} / \mathrm{d}$ could be obtained by using a correct supplementation program (Poppi and McLennan, 1995; Paulino et al., 2008). The nutritional evaluation of tropical grasses under grazing during the rainy season indicates an unbalanced energy-toprotein ratio exists, with a relative excess of energy. Therefore, supplementation programs should focus primarily on the establishment of a dietary balance by increasing protein content in the diet. This dietary adequacy would allow for the utilization of this relative excess of energy from forage and convert it into body weight (BW) gain (Costa et al., 2011c). For this reason, supplementation during the rainy season should focus primarily on protein supplementation (Detmann et al., 2014a; Lazzarini et al., 2016).

Protein supplementation has been widely utilized for cattle under grazing during the rainy season (Figueiredo et al., 2008; Porto et al., 2009; Costa et al., 2011a). This pattern has characterized changes in the focus of supplementation utilization and type, since energy supplements were widely utilized in the rainy season without showing optimal improvements in nutritional performance and animal production (Detmann et al., 2014a; Lazzarini et al., 2016). However, comparative evaluations regarding protein and energy supplementation on nutritional and metabolic effects on animals under grazing in the tropics remain scarce.

Therefore, the objective of this study was to evaluate the effects of supplements with different crude protein (CP) contents in grazing cattle during rainy season on intake, digestibility, ruminal fermentation pattern, and characteristics of nitrogen metabolism.

\section{MATERIAL AND METHODS}

The experiment was conducted between January and March of 2010 (during the rainy season) at the Department of Animal Science at the Universidade Federal de Viçosa, Viçosa, Minas Gerais State, Brazil $\left(20^{\circ} 45^{\prime} \mathrm{S}, 42^{\circ} 52^{\prime} \mathrm{W}\right)$. All surgical and animal care procedures were approved by the University Animal Care Committee, that was registered under the protocol number 16/2010.

Five ruminally and abomasally fistulated Holstein $\times$ Zebu steers, averaging $296 \pm 14 \mathrm{~kg}$ of BW, were used in a $5 \times 5$ Latin square design. The steers were kept in individual signal grass (Brachiaria decumbens Stapf.) paddocks of approximately 0.34 ha. Water and a mineral mixture were available to the steers at all times. A corral annexed to the paddocks was used for management of animals and sampling.

Five treatments were evaluated: a control (without supplementation) and supplements formulated to contain 0 ,
330,670 , and $1,000 \mathrm{~g}$ of $\mathrm{CP} / \mathrm{kg}$ as-fed, provided daily at $1 \mathrm{~g}$ of supplement (as-fed) $/ \mathrm{kg} \mathrm{BW}$. The supplement containing $0 \mathrm{~g} \mathrm{CP} / \mathrm{kg}$ was composed entirely of corn starch (Amisol 3408, Corn Products Co, Santana do Parnaíba, SP, Brazil), whereas supplement containing $1,000 \mathrm{~g} \mathrm{CP} / \mathrm{kg}$ was composed by soybean meal $(740 \mathrm{~g} / \mathrm{kg})$ and a mixture of urea:ammonium sulphate $(9: 1 ; 260 \mathrm{~g} / \mathrm{kg})$. The supplements with 330 and $660 \mathrm{~g} \mathrm{CP} / \mathrm{kg}$ corresponded to the replacement of $1 / 3$ and $2 / 3$ of the corn starch by the protein supplement. The supplement amount was calculated based on each animal's BW at the beginning of each experimental period, and infused once daily (1200h) in the rumen of animals during the experimental period.

Each experimental period lasted $16 \mathrm{~d}$, with $5 \mathrm{~d}$ for supplement adaptation and $11 \mathrm{~d}$ for sample collection. Steers were weighed at the beginning and at the end of each experimental period. The available forage in the pasture was estimated by cutting five square areas $(0.5 \times 0.5 \mathrm{~m})$ in each paddock that were randomly chosen on the first day of each experimental period. The samples were oven-dried $\left(60^{\circ} \mathrm{C}\right)$, processed in a knife mill $(1-\mathrm{mm})$, and analysed for dry matter (DM) content (method INCT-CA G-003/1; Detmann et al., 2012). The average forage availability during the experiment was $4.20 \pm 0.12$ ton $\mathrm{DM} / \mathrm{ha}$.

The evaluation of the consumed forage was performed by hand-plucked sampling that was performed on the first, fifth, and ninth days of each experimental period. The samples were oven-dried $\left(60^{\circ} \mathrm{C}\right)$ and processed in a knife mill (TE-650, Tecnal, Piracicaba, SP, Brazil) to pass through a $2-\mathrm{mm}$ screen sieve. Approximately $50 \%$ of the ground material was processed again in the same mill to pass through a 1-mm screen sieve. Pooled samples were produced for each paddock and experimental period.

Fecal excretion was estimated using titanium dioxide as an external marker. The marker was infused $(20 \mathrm{~g} / \mathrm{d})$ into the rumen of each animal at $1200 \mathrm{~h}$ from the first to the eighth day of each experimental period. Fecal and abomasal samples were taken from the rectum of each animal according to the following schedule: Sixth day, 0800h and 1400h; seventh day, $1000 \mathrm{~h}$ and $1600 \mathrm{~h}$; and eighth day, $1200 \mathrm{~h}$ and $1800 \mathrm{~h}$. The fecal and abomasal samples were oven-dried $\left(60^{\circ} \mathrm{C}\right)$ and processed as previously described. Pooled samples were produced for each animal and experimental period.

Samples of ruminal fluid were taken on the ninth day of each experimental period at $0600 \mathrm{~h}, 1200 \mathrm{~h}, 1800 \mathrm{~h}$, and $2400 \mathrm{~h}$ to evaluate the rumen $\mathrm{pH}$, ruminal ammonia nitrogen (RAN), and volatile fatty acids (VFA; acetate, propionate, and butyrate) concentration. The samples were collected manually from the liquid-solid interface of the rumen mat, filtered through a triple layer of cheesecloth, and submitted for a $\mathrm{pH}$ assessment using a digital potentiometer (TEC-3P- 
MP, Tecnal, Piracicaba, SP, Brazil). Then, an 8-mL aliquot of ruminal fluid was fixed with $2 \mathrm{~mL}$ of a metaphosphoric acid solution $(250 \mathrm{~g} / \mathrm{L})$ and frozen $\left(-20^{\circ} \mathrm{C}\right)$ for subsequent analysis of VFA. A $40-\mathrm{mL}$ aliquot was subsequently fixed with $1 \mathrm{~mL}$ of $\mathrm{H}_{2} \mathrm{SO}_{4}(500 \mathrm{~g} / \mathrm{L})$, and frozen $\left(-20^{\circ} \mathrm{C}\right)$ for posterior RAN analysis. Rumen microorganisms were isolated on the nineth day of each experimental period. Samples of rumen contents were taken immediately before $(1200 \mathrm{~h})$ and $6 \mathrm{~h}$ after the supplementation (1800h), according to Cecava et al. (1990).

On the tenth day of each experimental period, urine spot samples were obtained two hours before (1000h) and four hours after $(1600 \mathrm{~h})$ supplementation. The samples were filtered through cheesecloth, and a $10-\mathrm{mL}$ aliquot was separated, diluted with $40 \mathrm{~mL} \mathrm{H}_{2} \mathrm{SO}_{4}(0.036 \mathrm{~N})$, and frozen $\left(-20^{\circ} \mathrm{C}\right)$. Concomitantly to the urine samples, blood was collected from the jugular vein of each animal using test tubes containing separator gel and a coagulation accelerator (BD Vacuntainer SST II Advance, Becton Dickinson and Company, Franklin Lakes, NJ, USA). The samples were centrifuged at $2,700 \times \mathrm{g}$ for 20 minutes to obtain the serum, which was frozen $\left(-20^{\circ} \mathrm{C}\right)$.

Forage, supplements, abomasal digesta, and fecal samples (processed to pass through a $1-\mathrm{mm}$ screen sieve) were analysed for DM (method INCT-CA G-003/1), organic matter (OM; method INCT-CA M-001/1), CP (method INCT-CA N-001/1), and neutral detergent fiber corrected for ash and protein (NDFap; using thermostable $\alpha$-amylase and omitting the use of sodium sulfite; methods INCT-CA F-002/1, INCT-CA M-002/1, and INCT-CA N-004/1) contents, according to the standard methods for feed analysis of the Brazilian National Institute of Science and Technology in Animal Science (INCT-CA; Detmann et al., 2012; Table 1).

The fecal samples were evaluated for titanium dioxide content according to a colorimetric method (method INCTCA M-007/1; Detmann et al., 2012). The fecal excretion of DM was obtained as the ratio of the daily dose to the fecal

Table 1. Composition of supplements and forage

\begin{tabular}{|c|c|c|c|}
\hline \multirow{2}{*}{ Item } & \multicolumn{2}{|c|}{ Supplement $^{1}$} & \multirow{2}{*}{ Forage $^{2,3}$} \\
\hline & Protein & Starch & \\
\hline $\mathrm{DM}, \mathrm{g} / \mathrm{kg}$ (as fed) & 871.0 & 895.2 & $256.4 \pm 0.81$ \\
\hline $\mathrm{OM}$ & 956.0 & 999.5 & $921.2 \pm 0.24$ \\
\hline $\mathrm{CP}$ & 1256.0 & - & $122.5 \pm 0.51$ \\
\hline NDFap & 63.8 & - & $577.1 \pm 0.95$ \\
\hline NDIP & 5.3 & - & $208.9 \pm 1.65$ \\
\hline iNDF & 14.8 & - & $171.3 \pm 0.65$ \\
\hline
\end{tabular}

NDFap, neutral detergent fiber corrected for ash and protein; NDIP, neutral detergent insoluble protein; iNDF, indigestible NDF.

${ }^{1}$ Protein $=$ soybean meal+urea + ammonium sulfate.

${ }^{2}$ Hand-plucked samples.

${ }^{3}$ Mean \pm standard error of the mean. content of the marker. The estimates of forage intake were obtained using indigestible NDF (iNDF) as an internal marker. The iNDF contents in feces and forage were estimated in the samples processed to pass a $2-\mathrm{mm}$ screen sieve using a 288-hours in situ incubation procedure (method INCT-CA F-008/1; Detmann et al., 2012). Digesta flow entering the abomasum was calculated by dividing average intake of iNDF by abomasal concentration of iNDF.

The RAN content in the ruminal fluid samples was evaluated using an indophenol colorimetric method (method INCT-CA N-006/1; Detmann et al., 2012). The concentrations obtained at the different sampling times were pooled by animal and period to obtain a single value that represented the average daily RAN concentration. Ruminal $\mathrm{pH}$ values were combined in a similar manner. Rumen fluid samples for VFA analysis were pooled by animal and experimental period (equal volumes per sampling time) and analysed by high-performance liquid chromatography as described by Batista et al. (2016).

Blood serum samples, after thawing, were analysed for urea concentration (enzyme-colorimetric method, Bioclin K047, Quibasa Química Básica Ltda, Belo Horizonte, MG, Brazil).

After thawing, urine samples were pooled by animal and experimental period and then analyzed for creatinine contents estimated by the modified Jaffé method (Bioclin K016-1, Brazil), total nitrogen (N) content (method INCTCA N-001/1; Detmann et al., 2012), and urea (enzymecolorimetric method, Bioclin K047, Brazil). Total urinary volume was estimated using the ratio of creatinine excretion per unit of BW to its concentration in the urine (Chizzotti et al., 2006). The rumen microorganism samples were oven dried $\left(60^{\circ} \mathrm{C}\right)$ and assessed for DM, CP (as described above), and purine bases (Ushida et al., 1985) contents. The purine bases were used to assess microbial concentrations in the abomasal digesta based on the $\mathrm{N}_{\mathrm{RNA}}: \mathrm{N}_{\text {total }}$ ratio in rumen microorganisms.

Statistical analysis were performed using the MIXED procedure of SAS 9.4 (SAS Inst. Inc., Cary, NC, USA) according to a $5 \times 5$ Latin square design including the fixed effect of treatments and the random effects of animals and experimental periods. Comparisons among treatments were performed by using a set of orthogonal contrasts, which included an overall comparison between supplemented and non-supplemented treatments and the linear, quadratic, and cubic effects associated with the $\mathrm{CP}$ content in the supplements $(0,330,670$, and $1,000 \mathrm{~g} / \mathrm{kg})$. Statistical significance was considered at $\mathrm{p} \leq 0.05$, and tendencies were considered at $0.05<\mathrm{p} \leq 0.10$. All data from 2 steers (treatment with $0 \mathrm{~g} \mathrm{CP} / \mathrm{kg}$ and $1,000 \mathrm{~g} \mathrm{CP} / \mathrm{kg}$ in the first and fifth period, respectively) were lost because of problems unrelated to the treatments. 


\section{RESULTS}

The intake $(\mathrm{kg} / \mathrm{d})$ of total DM, forage DM, OM, CP, NDFap, digested OM (DOM), and digested NDFap were, on average, improved $(\mathrm{p} \leq 0.023)$ by the supplementation (Table 2). In addition, there was a positive linear effect $(\mathrm{p} \leq 0.033)$ of the supplement $\mathrm{CP}$ content on $\mathrm{OM}, \mathrm{CP}$, and DOM intakes. There was a tendency $(p \leq 0.08)$ of linear increase in total $\mathrm{DM}$ and forage $\mathrm{DM}$ intake due to increasing levels of supplement $\mathrm{CP}$ content. The variation of CP concentration in the supplements did not affect $(p \geq 0.219)$ the NDFap and digested NDF intakes. No effect of the supplements was observed $(\mathrm{p} \geq 0.11)$ on iNDF intake.

Upon comparing voluntary intake values in relation to the BW of animals $(\mathrm{g} / \mathrm{kg} \mathrm{BW})$, it was observed that supplementation increased $(\mathrm{p} \leq 0.007)$ total $\mathrm{DM}$, forage $\mathrm{DM}$, $\mathrm{OM}$, and NDFap intakes. Additionally, total DM, forage $\mathrm{DM}$, and $\mathrm{OM}$ intakes were linear and positively affected ( $\leq \leq 0.025)$ by varying the $\mathrm{CP}$ concentration in supplements, while NDFap intake tended to increase linearly $(p=0.094)$ with increases in supplement $\mathrm{CP}$ content (Table 2).

Supplementation did not affect $(\mathrm{p} \geq 0.158)$ total $\mathrm{OM}$ and CP digestibilities or dietary DOM content when compared to the control treatment; though supplementation increased $(\mathrm{p}=0.041)$ total NDFap digestibility (Table 3$)$. The increase in supplement $\mathrm{CP}$ content had a positive linear effect $(p=0.007)$ on total $\mathrm{CP}$ digestibility, and tended $(\mathrm{p}=$ 0.069 ) to linearly increase OM digestibility. A tendency for a quadratic effect $(\mathrm{p} \leq 0.099)$ of supplement CP content on the total NDFap digestibility and dietary content of DOM were observed. For these two variables, the tendency for a quadratic effect was associated with higher observed estimates with a CP concentration of $670 \mathrm{~g} / \mathrm{kg}$ and a small decrease when the CP content was increased to $1,000 \mathrm{~g} / \mathrm{kg}$ (Table 3).

On average, the provision of supplements did not increase $(\mathrm{p} \geq 0.105)$ the ruminal digestibilities of $\mathrm{OM}, \mathrm{CP}$, and NDFap (Table 3). However, increasing supplement CP content caused a positive linear effect $(\mathrm{p} \leq 0.018)$ on ruminal digestibilities of $\mathrm{OM}$ and $\mathrm{CP}$. Additionally, a quadratic effect of the supplement $\mathrm{CP}$ content was observed $(\mathrm{p}=$ 0.041 ) for the ruminal digestibility of NDFap, with the highest estimate obtained with a CP content of $670 \mathrm{~g} / \mathrm{kg}$. No effect was observed $(\mathrm{p} \geq 0.155) \quad$ on the intestinal digestibilities.

On average, supplement supply decreased $(p=0.003)$ ruminal $\mathrm{pH}$ compared to the control (Table 4). In addition, there was a cubic effect $(p=0.017)$ of supplement $C P$ content on this variable. An inspection of treatment means indicates that there was a decrease in ruminal $\mathrm{pH}$ with the replacement of protein supplement by starch. Supplying supplements increased $(\mathrm{p}<0.001)$ RAN concentrations, which also were linearly and positively $(\mathrm{p}<0.001)$ affected by $\mathrm{CP}$ content in supplements.

Total VFA concentrations in rumen fluid was decreased $(p=0.026)$ by providing supplements (Table 4). Additionally, the change in supplement $\mathrm{CP}$ content caused a tendency for a quadratic effect $(p=0.057)$ on total VFA concentrations, with more prominent decreases observed for the intermediate $\mathrm{CP}$ contents $(330$ and $670 \mathrm{~g} / \mathrm{kg})$.

Table 2. Effects of supplements with different protein contents on voluntary intakes in grazing cattle during the rainy season

\begin{tabular}{|c|c|c|c|c|c|c|c|c|c|c|}
\hline \multirow{2}{*}{ Item } & \multicolumn{5}{|c|}{ Treatments $^{1}$} & \multirow{2}{*}{$\mathrm{S}$} & \multicolumn{4}{|c|}{ p-value ${ }^{2}$} \\
\hline & Control & 0 & 330 & 670 & 1,000 & & $\mathrm{C}$ vs $\mathrm{S}$ & $\mathrm{L}$ & Q & $\mathrm{C}$ \\
\hline & & & & 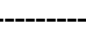 & ----- k & 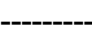 & 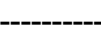 & 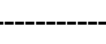 & $\cdots$ & --------. \\
\hline Total DM & 5.636 & 6.409 & 6.695 & 6.750 & 7.345 & 0.654 & 0.006 & 0.080 & 0.636 & 0.574 \\
\hline Forage DM & 5.636 & 6.130 & 6.438 & 6.489 & 7.074 & 0.656 & 0.023 & 0.078 & 0.670 & 0.566 \\
\hline Supplement DM & - & 0.270 & 0.257 & 0.261 & 0.257 & - & - & - & - & - \\
\hline $\mathrm{OM}$ & 5.110 & 5.633 & 6.249 & 6.247 & 6.781 & 0.625 & 0.005 & 0.033 & 0.893 & 0.384 \\
\hline $\mathrm{CP}$ & 0.757 & 0.706 & 0.840 & 1.054 & 1.224 & 0.132 & 0.014 & $<0.001$ & 0.781 & 0.657 \\
\hline NDFap & 3.004 & 3.596 & 3.866 & 3.798 & 4.035 & 0.430 & 0.004 & 0.219 & 0.939 & 0.476 \\
\hline iNDF & 0.984 & 1.100 & 1.107 & 0.999 & 1.168 & 0.123 & 0.110 & 0.736 & 0.197 & 0.147 \\
\hline Digested OM & 2.818 & 3.070 & 3.714 & 3.921 & 4.254 & 0.557 & 0.009 & 0.014 & 0.581 & 0.629 \\
\hline Digested NDF & 1.718 & 2.133 & 2.513 & 2.517 & 2.533 & 0.419 & 0.008 & 0.225 & 0.389 & 0.655 \\
\hline Total DM & 19.0 & 21.6 & 22.9 & 22.5 & 25.4 & 1.9 & 0.001 & 0.025 & 0.423 & 0.220 \\
\hline Forage DM & 19.0 & 20.7 & 22.0 & 21.7 & 24.5 & 1.9 & 0.007 & 0.024 & 0.427 & 0.218 \\
\hline OM & 17.2 & 18.9 & 21.4 & 20.8 & 23.5 & 1.8 & 0.001 & 0.009 & 0.897 & 0.124 \\
\hline NDFap & 10.1 & 12.1 & 13.3 & 12.7 & 14.1 & 1.4 & 0.001 & 0.094 & 0.900 & 0.194 \\
\hline
\end{tabular}

DM, dry matter; OM, organic matter; CP, crude protein; NDFap, neutral detergent fiber corrected for ash and protein; iNDF, indigestible NDF.

${ }^{1} \mathrm{Control}=$ without supplementation; $0,330,670$, and 1,000 = crude protein content in the supplements $(\mathrm{g} / \mathrm{kg}$ as-fed).

${ }^{2} \mathrm{C}$ vs S, comparison between the control (without supplementation) and treatments with supplements; L, linear; Q, quadratic; C, cubic effect of the crude protein content in the supplements. 
Table 3. Effects of supplements with different protein contents on total, ruminal, and intestinal digestibilities (g/g) in grazing cattle during the rainy season

\begin{tabular}{|c|c|c|c|c|c|c|c|c|c|c|}
\hline \multirow{2}{*}{ Item } & \multicolumn{5}{|c|}{ Treataments $^{1}$} & \multirow{2}{*}{$\mathrm{s}$} & \multicolumn{4}{|c|}{ p-value ${ }^{2}$} \\
\hline & Control & 0 & 330 & 670 & 1,000 & & C vs $\mathrm{S}$ & $\mathrm{L}$ & Q & $\mathrm{C}$ \\
\hline \multicolumn{11}{|l|}{ Total } \\
\hline $\mathrm{OM}$ & 0.552 & 0.530 & 0.592 & 0.616 & 0.608 & 0.057 & 0.265 & 0.069 & 0.229 & 0.949 \\
\hline $\mathrm{CP}$ & 0.613 & 0.587 & 0.637 & 0.700 & 0.735 & 0.067 & 0.158 & 0.007 & 0.820 & 0.784 \\
\hline NDFap & 0.573 & 0.586 & 0.649 & 0.655 & 0.632 & 0.048 & 0.041 & 0.224 & 0.099 & 0.777 \\
\hline DOM (g/kg DM) & 501 & 466 & 553 & 570 & 563 & 53 & 0.190 & 0.027 & 0.097 & 0.684 \\
\hline \multicolumn{11}{|l|}{ Ruminal $^{3}$} \\
\hline $\mathrm{OM}$ & 0.353 & 0.332 & 0.379 & 0.441 & 0.443 & 0.062 & 0.178 & 0.018 & 0.476 & 0.569 \\
\hline $\mathrm{CP}$ & 0.323 & 0.245 & 0.352 & 0.459 & 0.500 & 0.123 & 0.317 & 0.010 & 0.583 & 0.789 \\
\hline NDFap & 0.584 & 0.558 & 0.645 & 0.678 & 0.646 & 0.053 & 0.105 & 0.034 & 0.041 & 0.904 \\
\hline \multicolumn{11}{|l|}{ Intestinal $^{3}$} \\
\hline $\mathrm{OM}$ & 0.308 & 0.303 & 0.342 & 0.317 & 0.294 & 0.057 & 0.857 & 0.700 & 0.281 & 0.567 \\
\hline $\mathrm{CP}$ & 0.433 & 0.432 & 0.442 & 0.446 & 0.589 & 0.051 & 0.632 & 0.416 & 0.898 & 0.854 \\
\hline NDFap & -0.033 & 0.033 & 0.012 & -0.07 & -0.040 & 0.087 & 0.717 & 0.155 & 0.553 & 0.350 \\
\hline
\end{tabular}

OM, organic matter; CP, crude protein; NDFap, neutral detergent fiber corrected for ash and protein; DOM, digested organic matter; DM, dry matter.

${ }^{1} \mathrm{Control}=$ without supplementation; $0,330,670$, and $1,000=$ crude protein content in the supplements (g/kg as-fed).

${ }^{2} \mathrm{C}$ vs S, comparison between the control (without supplementation) and treatments with supplements; L, linear; Q, quadratic; C, cubic effect of the crude protein content in the supplements.

${ }^{3}$ Calculated as a fraction of inflow minus outflow of compound in the compartment.

Supplementation increased $(p=0.014)$ the molar proportion of butyrate, but did not change ( $\mathrm{p} \geq 0.23)$ the acetate and propionate molar proportions, or the acetate:propionate ratio in the ruminal fluid. The propionate molar proportion decreased linearly $(p=0.02)$, whereas the acetate molar proportion tended to increase linearly $(\mathrm{p}=0.064)$ with increasing supplement $\mathrm{CP}$ content. Therefore, there was a positive linear effect $(\mathrm{p}=0.036)$ of supplement $\mathrm{CP}$ on the acetate:propionate ratio (Table 4).

Supplementation increased $(\mathrm{p}<0.001)$ serum urea $\mathrm{N}$ (SUN) concentrations, which also increased linearly $(p<0.001)$ with increasing supplement CP content (Table 5). Supplementation also increased $(\mathrm{p} \leq 0.014) \mathrm{N}$ intake and urinary $\mathrm{N}$ excretion, but did not affect $(\mathrm{p}=0.494)$ the fecal $\mathrm{N}$ excretion. However, there was a tendency for a quadratic effect $(\mathrm{p}=0.082)$ of $\mathrm{CP}$ content on urinary $\mathrm{N}$ excretion. The quadratic effect was attributed to a small decrease in excretion observed for the supplement at $330 \mathrm{~g} \mathrm{CP} / \mathrm{kg}$. Likewise, urinary urea $\mathrm{N}$ excretion showed a quadratic effect $(\mathrm{p}=0.037)$ and a similar pattern of total urinary $\mathrm{N}$ excretion. Fecal $\mathrm{N}$ excretion was not affected $(\mathrm{p} \geq 0.799)$ by supplement $\mathrm{CP}$ content. The apparent $\mathrm{N}$ balance (NB; g/d) and relative $\mathrm{N}$ balance (RNB; g/g nitrogen intake) were not, on average, changed $(\mathrm{p} \geq 0.164)$ by the supplementation (Table 5). However, both exhibited a tendency to increase linearly ( $\leq \leq 0.099)$ with increasing supplement $C P$ content. Supplementation increased $(\mathrm{p}=0.007)$ microbial $\mathrm{N}$ production in the rumen (NMIC), which also changed linearly and positively $(\mathrm{p}<0.016)$ with increasing supplement CP content. No effect was observed ( $\mathrm{p} \geq 0.168)$

Table 4. Effects of supplements with different protein contents on ruminal fermentation in grazing cattle during the rainy season

\begin{tabular}{|c|c|c|c|c|c|c|c|c|c|c|}
\hline \multirow{2}{*}{ Item } & \multicolumn{5}{|c|}{ Treataments $^{1}$} & \multirow{2}{*}{$\mathrm{S}$} & \multicolumn{4}{|c|}{ p-value ${ }^{2}$} \\
\hline & Control & 0 & 330 & 670 & 1,000 & & C vs S & $\mathrm{L}$ & Q & $\mathrm{C}$ \\
\hline$\overline{\mathrm{pH}}$ & 6.97 & 6.54 & 6.87 & 6.82 & 6.94 & 0.10 & 0.003 & 0.004 & 0.064 & 0.017 \\
\hline RAN & 7.53 & 7.72 & 9.70 & 11.86 & 14.63 & 0.74 & $<0.001$ & $<0.001$ & 0.294 & 0.788 \\
\hline Total VFA & 6.06 & 5.83 & 5.44 & 5.41 & 5.73 & 0.35 & 0.026 & 0.705 & 0.057 & 0.989 \\
\hline \multicolumn{11}{|c|}{ Molar proportion $(\mathrm{mmol} / 100 \mathrm{mmol})$} \\
\hline Acetate & 72.9 & 68.7 & 72.3 & 71.7 & 72.6 & 2.4 & 0.230 & 0.064 & 0.268 & 0.271 \\
\hline Propionate & 19.2 & 22.4 & 18.9 & 18.9 & 18.2 & 2.1 & 0.688 & 0.020 & 0.190 & 0.355 \\
\hline Butyrate & 7.9 & 8.9 & 8.8 & 9.4 & 9.2 & 0.7 & 0.014 & 0.306 & 0.881 & 0.337 \\
\hline Acetate:propionate & 3.83 & 3.09 & 3.83 & 3.97 & 4.00 & 0.54 & 0.709 & 0.036 & 0.201 & 0.646 \\
\hline
\end{tabular}

RAN, ruminal ammonia nitrogen concentration (mg/dL); VFA, volatile fatty acids.

${ }^{1}$ Control = without supplementation; $0,330,670$, and 1,000 = crude protein content in the supplements (g/kg as-fed).

${ }^{2} \mathrm{C}$ vs S, comparison between the control (without supplementation) and treatments with supplements; L, linear; Q, quadratic; C, cubic effect of the crude protein content in the supplements 
Table 5. Effects of supplements with different protein contents on nitrogen metabolism in grazing cattle during the rainy season

\begin{tabular}{|c|c|c|c|c|c|c|c|c|c|c|}
\hline \multirow{2}{*}{ Item } & \multicolumn{5}{|c|}{ Treatments $^{1}$} & \multirow{2}{*}{$\mathrm{s}$} & \multicolumn{4}{|c|}{ p-value ${ }^{2}$} \\
\hline & Control & 0 & 330 & 670 & 1,000 & & $\mathrm{C}$ vs $\mathrm{S}$ & L & Q & $\mathrm{C}$ \\
\hline SUN & 8.33 & 9.24 & 12.86 & 15.75 & 19.81 & 1.66 & $<0.001$ & $<0.001$ & 0.783 & 0.581 \\
\hline NI & 121.2 & 113.0 & 134.5 & 168.6 & 195.8 & 21.1 & 0.014 & $<0.001$ & 0.780 & 0.657 \\
\hline FNE & 44.9 & 46.9 & 47.7 & 47.7 & 48.4 & 7.7 & 0.494 & 0.799 & 0.984 & 0.927 \\
\hline UNE & 52.1 & 75.4 & 67.3 & 97.1 & 118.4 & 16.0 & 0.001 & 0.001 & 0.082 & 0.184 \\
\hline NB & 24.1 & -10.4 & 19.4 & 23.7 & 27.9 & 23.7 & 0.473 & 0.051 & 0.287 & 0.611 \\
\hline RNB & 0.161 & -0.074 & 0.119 & 0.094 & 0.111 & 0.129 & 0.164 & 0.099 & 0.184 & 0.344 \\
\hline UEUN & 37.8 & 37.4 & 32.7 & 74.4 & 105.9 & 11.8 & 0.014 & $<0.001$ & 0.037 & 0.107 \\
\hline NMIC & 44.1 & 59.0 & 72.1 & 71.0 & 97.7 & 18.1 & 0.007 & 0.016 & 0.446 & 0.279 \\
\hline EMS & 98.7 & 122.1 & 123.0 & 132.0 & 151.2 & 44.2 & 0.168 & 0.348 & 0.678 & 0.983 \\
\hline
\end{tabular}

SUN, serum urea nitrogen $(\mathrm{mg} / \mathrm{dL})$; NI, nitrogen intake (g/d); FNE, fecal nitrogen excretion (g/d); UNE, urinary nitrogen excretion (g/d); NB, apparent nitrogen balance $(\mathrm{g} / \mathrm{d})$; RNB, relative nitrogen balance ( $\mathrm{g} / \mathrm{g}$ of NI); UEUN, urinary excretion of ureic nitrogen $(\mathrm{g} / \mathrm{d})$; NMIC, microbial nitrogen production in the rumen (g/d); EMS, efficiency of microbial protein synthesis (g microbial CP/ $\mathrm{kg} \mathrm{DOM})$; DOM, digested organic matter $(\mathrm{kg} / \mathrm{d})$.

${ }^{1}$ Control $=$ without supplementation; $0,330,670$, and 1,000 = crude protein content in the supplements ( $\mathrm{g} / \mathrm{kg}$ as-fed).

${ }^{2} \mathrm{C}$ vs S, comparison between the control (without supplementation) and treatments with supplements; L, linear; Q, quadratic; C, cubic effect of the crude protein content in the supplements.

on the efficiency of microbial protein synthesis, which exhibited an average value of $125.4 \mathrm{~g}$ microbial $\mathrm{CP} / \mathrm{kg}$ DOM.

\section{DISCUSSION}

The supplementation provided in this study stimulated forage intake (Table 2), with strong evidence of a positive interaction effect between forage and supplement on dietary nutritional value (Paulino et al., 2008). However, this positive effect on intake was not homogeneous among the supplements, as an observed increased on forage intake as the protein content of supplements increased.

During periods of rapid growth for tropical grasses, such as the rainy season, the available forage represents a diet containing a relative excess of energy in relation to protein concentration (Detmann et al., 2014a). Thus, considering that a balanced protein-to-energy ratio is a determining factor for maximizing voluntary intake (Illius and Jessop, 1996; Forbes, 2003), adding protein via supplementation could provide improved dietary equilibrium. This could decrease the metabolic discomfort of the animal, avoiding the replacement of forage by supplement and, in some cases, stimulating greater amounts of forage intake, as observed in this study (Table 2). Detmann et al. (2014b) reported that forage intake is maximized by raising the dietary $\mathrm{CP}: \mathrm{DOM}$ ratio close to $288 \mathrm{~g} / \mathrm{kg}$, a value similar the one obtained through supplementation with a supplement protein content of 1,000 $\mathrm{g} \mathrm{CP} / \mathrm{kg}$ (Figure 1).

Additionally, the provision of protein supplements has been associated with improvements in $\mathrm{N}$ status in the body. Nitrogen status defines the quantitative and qualitative availability of $\mathrm{N}$ compounds for all physiological functions in animal metabolism, including functions associated with the metabolism of other compounds, such as energy substrates (Detmann et al., 2014b). Increases in voluntary forage intake have been associated with adjustments of $\mathrm{N}$ status (Egan, 1965; Egan and Moir, 1965; Kempton et al., 1977). In spite of a small stimuli on ruminal digestion of fiber with increasing supplement $\mathrm{CP}$ content, it is reasonable to assume that most of the stimuli on forage intake caused by supplemental CP (Table 3) would predominantly stem from post-digestive or metabolic effects (Egan and Moir, 1965; Detmann et al., 2014b).

Moreover, the use of exclusive energy supplement $(0 \mathrm{~g}$ $\mathrm{CP} / \mathrm{kg}$ ) did not result in a numeric decrease in forage intake compared to the control treatment (Table 2), which apparently contradicts the previous results presented by other authors studying in tropical conditions (Detmann et al., 2001; Costa et al., 2011b). However, the CP content of forage in this study $(122.5 \mathrm{~g} \mathrm{CP} / \mathrm{kg} \mathrm{DM})$ was above the typical average values observed in tropical grasses during the rainy season (94.2 g CP/kg DM; Detmann et al., 2014a).

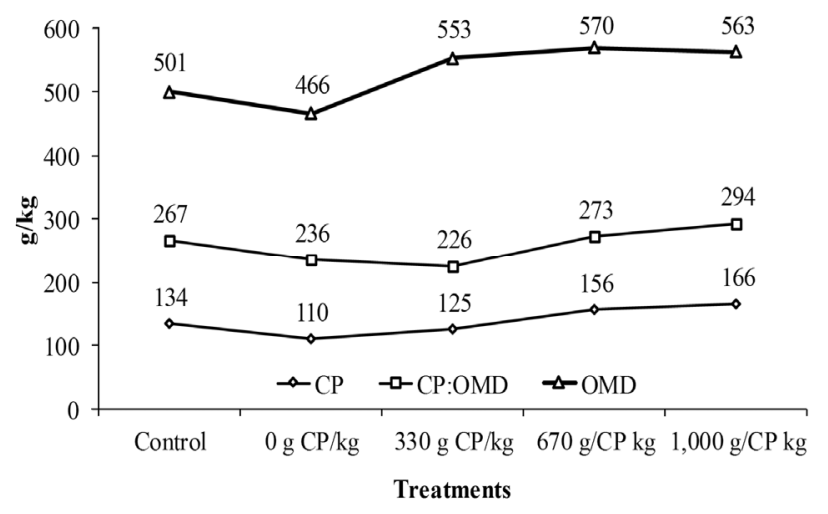

Figure 1. Dietary contents of crude protein (CP; g/ $\mathrm{kg} \mathrm{DM})$, dietary digested organic matter (DOM; $\mathrm{g} / \mathrm{kg} \mathrm{DM})$ and the dietary $\mathrm{CP}$ :DOM ratio $(\mathrm{g} / \mathrm{kg})$ according to different treatments. DM, dry matter. 
Thus, in such a situation, energy supplementation would cause less interference on the dietary protein-to-energy ratio (Figure 1), leading to the absence of deleterious effects on forage intake, which was also observed by Lazzarini et al. (2016). At least part of the positive effects of the energy supplement on intake may be associated with stimulation of NMIC (Table 5), which provides an increased level of MP through the additional energy provided via supplementation.

Although no negative effect was observed on the ruminal digestibility of fiber, on average, an observed increase in total NDFap digestibility was observed when providing supplements (Table 3 ). Under normal conditions, supplementation increases the occurrence of the "carbohydrate effect", which increases competition for essential nutrients between groups of microbial species (ElShazly et al., 1961; Mould et al., 1983) and disfavours the use of insoluble fiber by fibrolytic microorganisms (Costa et al., 2008; Zorzi et al., 2009), which presents lower growth rates and subsequently reduced competitive capacity (Carvalho et al., 2011). However, the high protein concentration of forage used in this study (Table 1; Figure 1) may have decreased the competition for $\mathrm{N}$ substrates in the rumen (Zorzi et al., 2009), thereby preventing the occurrence of the prominent negative effects of non-fibrous carbohydrates on the rumen digestion of insoluble fiber. In this situation, the stimulations were observed on rumen microbial production (Table 5), supporting the increased ruminal utilization of fiber carbohydrates resulting from supplementation. However, when the ruminal digestion of fiber is evaluated between supplemented animals, it was discovered that the use of energy supplements resulted in a lower utilization of fiber in the rumen compared to protein supplements. This indicates the presence of competition between microbial species, which appear to be reduced to the same extent that $\mathrm{CP}$ content in the supplement is increased (Table 3). This behaviour is supported by the positive association of protein concentration in supplements and RAN concentration (Table 4), indicating the increased availability of $\mathrm{N}$ substrates for microbial growth.

Supplementation did not lead to alteration of ruminal and total digestibilities of CP (Table 3). However, this behaviour must be viewed with caution when this type of comparison is based on the average response to supplemented treatments. An inspection of the individual means indicates that only energy supplementation lead to the depressed ruminal digestion of $\mathrm{CP}$, causing concomitant reduction in the total CP digestibility (Table 3 ). Since the use of energy and protein represents an integrated system in the rumen (Nocek and Russell, 1988), it is understood that an exclusive starch supplement resulted in the improved microbial assimilation of $\mathrm{N}$ from forage, resulting in greater NMIC compared to the control treatment (Table 5). As in this treatment, no additional supply of $\mathrm{N}$ existed, and greater microbial nitrogen assimilation decreased the $\mathrm{N}$ losses by diffusion-implying a decreased apparent digestibility of $\mathrm{CP}$ in the rumen, and adversely affecting dietary DOM content (Table 3). The RAN concentration was higher with the supplementation of starch compared to the control (Table 4), which is possibly due to a higher level of urea $\mathrm{N}$ transfer from the bloodstream, as this is stimulated by an increase in the amount of digested OM in the rumen (Kennedy et al., 1981; NRC, 1985).

The linear relationship between $\mathrm{CP}$ content in the supplement and CP ruminal digestibility (Table 3) is associated with the increase in RAN concentration (Table 4), which leads to increased transportation of $\mathrm{N}$ by diffusion into the bloodstream (NRC, 1985), which increases the SUN concentration (Table 5) and the apparent digestibility of $\mathrm{CP}$ in the rumen. However, with increasing CP intake (Table 2), there is a decreased contribution of metabolic fecal N to total fecal N (Van Soest, 1994), which causes increases in the total digestibility of CP (Table 3).

On average, supplementation did not affect NB or the efficiency of dietary $\mathrm{N}$ utilization, as measured by the relative balance of $\mathrm{N}$ compounds (BNR; Table 5). Similar to the observations for ruminal and total digestibilities of $\mathrm{CP}$, this behaviour must be viewed with caution when the comparison is based on the average response behaviour of supplemented treatments. Thus, an individual inspection of the means led to the realization that exclusive starch supplementation depressed NB and RNB. However, the increase in supplementary CP content linearly increased the NB and efficiency of $\mathrm{N}$ utilization (Table 5).

In ruminant animals, deposition of body tissue corresponds to interactive process in which the efficiency of utilization of metabolizable energy and protein are interrelated (Schroeder and Titgemeyer, 2008; Lazzarini et al., 2016). Upon analysing the increases in energy intake (i.e. DOM intake) and NMIC with exclusive starch supplementation compared to the control treatment (obtained with supplementation minus what was obtained in the control treatment), it was discovered that an excess of protein supply in relation to energy supply to metabolism occurred (Figure 2). This excess protein led to the increased elimination of nitrogenous compounds via urine, while decreasing the efficiency of $\mathrm{N}$ utilization (Table 5). Thus, energy supplementation, although it stimulated the forage intake, failed to improve $\mathrm{N}$ accretion in the body. This behaviour corroborates with the statement made by Detmann et al. (2014a), which suggested that energy supplementation for grazing animals during the rainy season may result in unoptimized effects on animal performance. It is noteworthy that increases in supplement $\mathrm{CP}$ content decreased the ratio of microbial $\mathrm{CP}$ on DOM 


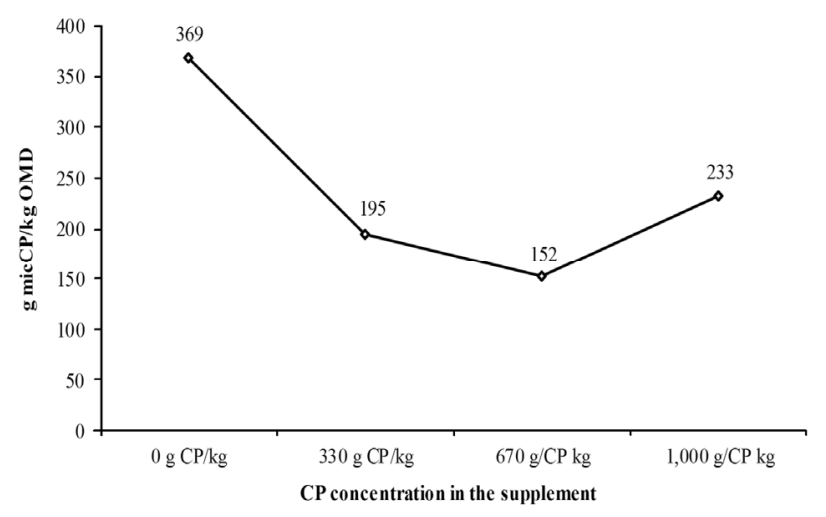

Figure 2. Relationship between the amount of microbial crude protein (micCP) and digested organic matter (DOM) intake compared to control according to different supplements.

intake compared to the control treatment (Figure 2).

On the other hand, increased $\mathrm{N}$ concentration incurred a linear increase on NB and RNB, reflecting the benefits of the exclusive protein supplementation $(1,000 \mathrm{~g} \mathrm{CP} / \mathrm{kg})$ for grazing animals during the rainy season. Considering the differences in NB and NMIC between supplements with 0 and $1,000 \mathrm{~g} \mathrm{CP} / \mathrm{kg}$, and assuming that microbial CP present about $64 \%$ of MP (NRC, 2001), it is logical that the increase in NB from raising the supplement $\mathrm{CP}$ concentration could be explained by the increase in ruminal microbial production.

However, despite the positive relationship between NB and NMIC in treatments involving supplementation, the trend of increasing $\mathrm{N}$ retention with an increase in supplemental $\mathrm{CP}$ cannot be fully explained by an increase in NMIC once a concomitant rise of urinary losses of $\mathrm{N}$ exists was observed (Table 5). Thus, the indirect effects of protein supplementation appear to act on the efficiency of $\mathrm{N}$ utilization by the animals. This behaviour reinforces the notion of post-digestive effects of protein supplementation, possibly associated with an increase in $\mathrm{N}$ status of the animal. This increase in $\mathrm{N}$ supply reduces the proportion of ingested $\mathrm{N}$ directed for survival and maintenance purposes, and increases the proportion of total $\mathrm{N}$ used for anabolic purposes. Consequently, it raises the overall efficiency of MP utilization (Detmann et al., 2014b; Batista et al., 2016), which increases the production of NMIC, and explains the positive linear relationship between $\mathrm{CP}$ concentration in supplements and the efficiency of $\mathrm{N}$ utilization (Table 5).

\section{CONCLUSION}

Energy supplementation for grazing cattle during the rainy season can increase forage intake and the production of microbial protein, while decreasing the efficiency of nitrogen utilization in animal metabolism. Moreover, apart from stimulating voluntary forage intake, protein supplementation besides to stimulate voluntary forage intake, results in greater efficiency in nitrogen utilization when compared to energy supplementation, representing a possible result of increased microbial protein synthesis in the rumen and improvements in nitrogen status in the body.

\section{CONFLICT OF INTEREST}

We certify that there is no conflict of interest with any financial organization regarding the material discussed in the manuscript.

\section{ACKNOWLEDGMENTS}

The authors thank the Conselho Nacional de Pesquisa e Desenvolvimento Científico (CNPq), the Fundcão de Amparo à Pesquisa de Minas Gerais (FAPEMIG), Instituto Nacional e Ciência e Tecnologia de Ciência Animal (INCTCiência Animal), and the CAPES (Coordenacão de Aperfeiçoamento de Pessoal de Nível Superior) for financial support.

\section{REFERENCES}

Batista, E. D., E. Detmann, E. C. Titgemeyer, S. C. Valadares Filho, R. F. D. Valadares, L. L. Prates, L. N. Rennó, and M. F. Paulino. 2016. Effects of varying ruminally undegradable protein supplementation on forage digestion, nitrogen metabolism, and urea kinetics in Nellore cattle fed low-quality tropical forage. J. Anim. Sci. 94:201-216.

Carvalho, I. P. C., E. Detmann, H. C. Mantovani, M. F. Paulino, S. C. Valadares Filho, V. A. C. Costa, and D. I. Gomes. 2011. Growth and antimicrobial activity of lactic acid bacteria from rumen fluid according to energy or nitrogen source. R. Bras. Zootec. 40:1260-1265.

Cecava, M. J., N. R. Merchen, L. C. Gay, and L. L. Berger. 1990. Composition of ruminal bacteria harvest from steers as influenced by dietary energy level, feeding frequency, and isolation techniques. J. Dairy Sci. 73:2480-2488.

Chizzotti, M. L, S. C.Valadares Filho, R. F. D. Valadares, F. H. M. Chizzotti, J. M. S. Campos, M. I. Marcondes, and M. A. Fonseca. 2006. Intake, digestibility and urinary excretion of urea and purine derivatives in heifers with different body weights. R. Bras. Zootec. 35:1813-1821.

Costa, V. A. C., E. Detmann, S. C. Valadares Filho, M. F. Paulino, L. T. Henriques, and H. C. Mantovani. 2008. In vitro degradation of low-quality tropical forage neutral detergent fiber according to protein and (or) carbohydrates supplementation. Rev. Bras. Zootec. 37:494-503.

Costa, V. A. C., E. Detmann, M. F. Paulino, S. C. Valadares Filho, L. T. Henriques, I. P. C. Carvalho, and T. N. P. Valente. 2011a. Intake and rumen dynamics of neutral detergent fiber in grazing cattle supplemented with non-protein nitrogen and, or true protein during the rainy season. R. Bras. Zootec. 40:28052814 . 
Costa, V. A. C., E. Detmann, M. F. Paulino, S. C. Valadares Filho, I. P. C. Carvalho, and L. P. Monteiro. 2011b. Intake and digestibility in cattle under grazing during rainy season and supplemented with different sources of nitrogenous compounds and carbohydrates. R. Bras. Zootec. 40:1788-1798.

Costa, V. A. C., E. Detmann, M. F. Paulino, S. C. V. Valadares Filho, L. T. Henriques, and I. P. C. Carvalho. 2011c. Total and partial digestibility and nitrogen balance in grazing cattle supplemented with non-protein and, or true protein nitrogen during the rainy season. R. Bras. Zootec. 40:2815-2826.

Detmann, E., M. F. Paulino, J. T. Zervoudakis, S. C. Valadares Filho, R. P. Lana, and D. S. Queiroz. 2001. Supplementation of crossbred steers during the rainy season: ingestive and digestive parameters. R. Bras. Zootec. 30:1340-1349.

Detmann, E., M. A. Souza, S. C. Valadares Filho, A. C. Queiroz, T. T. Berchielle, E. O. S. Saliba, L. S. Cabral, D. S. Pina, M. M. Ladeira, and J. A. G. Azevedo. 2012. Métodos para análise de alimentos (In Portuguese). 1st edn. Suprema, Visconde do Rio Branco, MG, Brazil.

Detmann, E., E. E. L. Valente, E. D. Batista, and P. Huhtanen. 2014a. An evaluation of the performance and efficiency of nitrogen utilization in cattle fed tropical grass pastures with supplementation. Livest. Sci. 162:141-153.

Detmann, E., M. F. Paulino, S. C. Valadares Filho, and P. Huhtanen. 2014b. Nutritional aspects applied to grazing cattle in the tropics: a review based on Brazilian results. Semin. Cienc. Agrar. 35:2829-2854.

Egan, A. R. 1965. Nutritional status and intake regulation in sheep. III. The relationship between improvement of nitrogen status and increase in voluntary intake of low-protein roughages by sheep. Aust. J. Agric. Res. 16:463-472.

Egan, A. R. and R. J. Moir. 1965. Nutritional status and intake regulation in sheep. I. Effects of duodenally infused single doses of casein, urea, and propionate upon voluntary intake of a low-protein roughage by sheep. Aust. J. Agric. Res. 16:437449.

El-Shazly, K., B. A. Dehority, and R. R. Johnson. 1961. Effect of starch on the digestion of cellulose in vitro and in vivo by rumen microorganisms. J. Anim. Sci. 20:268-273.

Figueiredo, D. M., M. F. Paulino, E. Detmann, E. H. B. K. Moraes, S. C. Valadares Filho, and M. G. Souza. 2008. Protein sources of in multiple supplements for cattle on pasture during the rainy season. R. Bras. Zootec. 37:2222-2232.

Forbes, J. M. 2003. The multifactorial nature of food intake control. J. Anim. Sci. 81:E139-E144.

Illius, A. W. and N. S. Jessop. 1996. Metabolic constraints on voluntary intake in ruminants. J. Anim. Sci. 74:3052-3062.

Kempton, T. J., J. V. Nolan, and R. A. Leng. 1977. Principles for the use of non-protein nitrogen and by-pass proteins in diets of ruminants. World Anim. Rev. 22:2-10.
Kennedy, P. M., R. T. J. Clarke, and L. P. Milligan. 1981. Influences of dietary sucrose and urea on transfer of endogenous urea to the rumen of sheep and numbers of epithelial bacteria. Br. J. Nutr. 46:533-541.

Lazzarini, I., E. Detmann, S. C. Valadares Filho, M. F. Paulino, E. D. Batista. L. M. A. Rufino, W. L. S. Reis, and M. O. Franco. 2016. Nutritional performance of cattle grazing during rainy season with nitrogen and starch supplementation. Asian Australas. J. Anim. Sci. 29:1120-1128.

Mould, F. L E. R. Ørskov, S. O. Mann, and S. A. Gauld. 1983. Associative effects of mixed feeds. II. The effect of dietary additions of bicarbonate salts on the voluntary intake and digestibility of diets containing various proportions of hay and barley. Anim. Feed Sci. Technol. 10:31-47.

NRC (National Research Council). 1985. Ruminant Nitrogen Usage. 1st edn. National Academy Press, Washington, DC, USA.

NRC (National Research Council). 2001. Nutrient Requirement of Dairy Cattle. 7th edn. National Academy Press, Washington, DC, USA.

Nocek, J. E. and J. B. Russell. 1988. Protein and energy as an integrated system. Relationship of ruminal protein and carbohydrate availability to microbial synthesis and milk production. J. Dairy Sci. 71:2070-2107.

Paulino, M. F., E. Detmann, E. E. L. Valente, and L. V. Barros. 2008. Nutrition of grazing cattle. In: Proceedings of the 4th Symposium on Strategic Management of Pasture (Eds. O. G. Pereira, J. A. Obeid, D. M. Fonseca, and D. Nascimento Jr.). Viçosa, MG, Brazil. pp. 131-169.

Poppi, D. P. and S. R. McLennan. 1995. Protein and energy utilization by ruminants at pasture. J. Anim. Sci. 73:278-290.

Porto, M. O., M. F. Paulino, S. C. Valadares Filho, M. F. L. Sales, M. I. Leão, and V. R. M. Couto. 2009. Protein sources in multiple supplements for finishing crossbred steers on Brachiaria pasture, in the wet season: productive and economical performance. R. Bras. Zootec. 38:1553-1560.

Schroeder, G. F. and E. C. Titgemeyer. 2008. Interaction between protein and energy supply on protein utilization in growing cattle: A review. Livest. Sci. 114:1-10.

Ushida, K., B. Lassalas, and J. Jouany. 1985. Determination of assay parameters for RNA analysis in bacterial and duodenal samples by spectrophotometry. Influence of treatment and preservation. Reprod. Nutr. Dev. 25:1037-1046.

Van Soest, P. J. 1994. Nutritional Ecology of the Ruminant. 2nd edn. Cornell University Press, Ithaca, NY, USA.

Zorzi, K., E. Detmann, A. C. Queiroz, M. F. Paulino, H. C. Mantovani, and G. F. Bayão. 2009. In vitro degradation of neutral detergent fiber of high-quality tropical forage according to supplementation with different nitrogenous compounds. R. Bras. Zootec. 38:964-971. 